\section{Agriculture in the Southern United States}

History of Agriculture in the Southern United States to 1860. By Lewis Cecil Gray, assisted by Esther Katherine Thompson. (Publication No. 430.) Vol. 1. Pp. xix +567 . Vol. 2. Pp. $\mathrm{ix}+569-1086$. (Washington, D.C. : Carnegie Institution, 1933.) n.p.

7 HE real history of agriculture in the southern the first crops by English colonists in Virginia in 1586, and from then onwards the pioneer farmers made their way by experiments along economic, biological and physical lines, until the present-day system of agricultural policy was evolved. Since 1908, Dr. Lewis Gray has been engaged in collecting and collating a wealth of material dealing with every aspect of this agricultural progress, and his published volumes make a permanent contribution to economic history, agricultural economics, technical agriculture and to the general social and political history of the South.

Geographical expansion and the beginnings of agricultural development progressed together throughout the colonial period, when such indistries as lumbering and the production of tobacco, rice and indigo were gradually developed. The necessary labour was assured by the evolution of the plantation system, at first based on indentured servitude of white people, and later on the forced labour of introduced African slaves. The slave trade became an integral part of the life of the South, and agricultural policy and the problems of slavery were intimately interwoven.

In the post colonial period, from 1785 onwards, the cotton industry assumed increasing importance, and sugar was also cultivated in addition to other long-established crops. As geographical expansion and regional development continued, the agricultural problems of the older settled districts became more marked with the increasing areas of soil exhaustion, and the depressing influence of western competition. These conditions led to attempts at agricultural and economic reorganisation, culminating in the agrarian movement of the middle of the nineteenth century, when conventions and committees endeavoured to put the agricultural industry on a sounder basis.

The presentation of the mass of detail is done in such interesting style that doubtless many will be led to read from cover to cover, while detailed indexes of contents, charts and tables render the book of inestimable value as a work of reference.

\section{The Interpretation of Life}

(1) The Universe and Life. By Prof. H. S. Jennings. (The Terry Lectures.) Pp. v+94. (New Haven, Conn.: Yale University Press; London: Oxford University Press, 1933.) 7s.6d. net.

(2) The Coming of Man: was it Accident or Design? By R. Broom. Pp. 238. (London: H. F. and G. Witherby, 1933.) 10s. $6 d$. net.

(1)

HOSE who had the privilege of listening
to the three lectures given by Prof. H. S. Jennings in Yale University, and now published in book form, must have found that his closely-woven argument demanded their keenest attention. "The purpose of these lectures," Prof. Jennings has written, "will be to show what positive outlook on life and the world is given by the study of biological science; and how this differs, if at all, from the outlook based on physics". In brief, these lectures represent the creed of one who is rightly regarded as one of the outstanding biologists of our time.

Prof. Jennings holds that the study of biology "lends no support to the doctrine of indeterminism that has become so rife in certain branches of physical science". Man may still hope for progress in body, mind and morals, for Nature's methods are really those of experimentation-ever leading on to new and more elaborate combination of characters and of qualities. $\mathrm{He}$ also holds that there are evidences of design everywhere, but the biologist, who seeks to explain contrivances in plants and animals by assuming the existence of an arch-designer, has to meet the still greater difficulty of explaining how such a contriving power came into being. The power of design is inherent in living matter. Further, Prof. Jennings maintains that there is no fact known to biologists which justifies the expectation of the return of life to things once dead, or the possibility of the human spirit existing outside the living human body.

These lectures are marked not only by great felicity of phrase but also by the manifestations of a courageous mind which has done its best to free itself from animus and emotion.

(2) This is the third book which Dr. Robert Broom has published since 1930. In the "Origin of the Human Skeleton" and in "The MammaIlike Reptiles of South Africa", he has drawn upon knowledge obtained during the many years he has devoted to the investigation of the fossiliferous 